\title{
Spatial ecology and habitat use of adult Booted Eagles (Aquila pennata) during the breeding season: implications for conservation
}

\author{
Pascual López-López ${ }^{1} \cdot$ Javier de La Puente ${ }^{2} \cdot$ Ugo Mellone $^{3} \cdot$ Ana Bermejo $^{2}$ • \\ Vicente Urios ${ }^{3}$
}

Received: 3 November 2015/Revised: 5 April 2016/Accepted: 12 May 2016/Published online: 25 May 2016

(C) Dt. Ornithologen-Gesellschaft e.V. 2016

\begin{abstract}
Fast-moving technological advances, such as satellite tracking technologies, are providing in-depth information of aspects of avian ecology hitherto unknown. In fact, detailed information about movement ecology and ranging behaviour of birds is important not only from the perspective of the basic ecology, but also from the conservation point of view. This is particularly important in European countries where agricultural intensification, land abandonment and the withdrawal of traditional management agro-forestry practices pose a threat to biodiversity. The Booted Eagle, likewise other forest raptors, is an adequate bioindicator of human-dominated agro-forestry Mediterranean landscapes in which low-intensity traditional agricultural practices still persist. Here, using a combination of an unbiased technology (i.e., GPS telemetry), a wide geographic extension of marked birds (all over Spain), and much larger sample size than in previous works, we provide the first quantitative assessment of the home range size and space use of the Booted Eagle by means of GPS satellite telemetry during the breeding season. Interestingly, our results revealed different levels of space use over the breeding season and showed that eagles
\end{abstract}

Communicated by T. Gottschalk.

Pascual López-López

Pascual.Lopez@uv.es

1 Terrestrial Vertebrates Group, Cavanilles Institute of Biodiversity and Evolutionary Biology, University of Valencia, Paterna, 46980 Valencia, Spain

2 SEO/BirdLife, Área de Estudio y Seguimiento de Aves, C/ Melquiades Biencinto, 34, 28053 Madrid, Spain

3 Vertebrates Zoology Group, Departamento de Ciencias Ambientales y Recursos Naturales, University of Alicante, Apdo. 99, 03080 Alicante, Spain perform long distance foraging movements (i.e., $>20 \mathrm{~km}$ ) from the nest throughout the breeding season. This resulted in larger home ranges than reported thus far, and, more interestingly, in an extremely eccentric topology of territories. Hence, management measures for conservation of forest raptors based on setting restrictions around nesting sites using buffer areas of arbitrary radii clearly results in large areas of eagles' home ranges laying outside "restriction" areas. Therefore, conservation measures should take into account the full range of agro-forestry habitats encompassed within the home range. Finally, our results support the claim that a large-scale management approach beyond the establishment of a closed network of protected areas such as the Natura 2000 network is necessary for the conservation of Mediterranean raptors.

Keywords Buffer areas - GPS · Home range - Movement ecology $\cdot$ Natura $2000 \cdot$ Satellite telemetry

\section{Zusammenfassung}

Räumliche Ökologie und Habitat-Nutzung bei adulten Zwergadlern (Aquila pennata) während der Brutzeit: Konsequenzen für den Artenschutz

Der rasante technische Fortschritt wie z. B. Verfahren zur Satelliten-gestützten Ortung macht in der Vogelökologie Informationen zugänglich, die in dieser Ausführlichkeit bislang unerreichbar waren. Tatsächlich ist detaillierte Information über die Bewegungs-Ökologie und das räumliche Verhalten von Vögeln nicht nur aus rein ökologischer Sicht wichtig, sondern auch unter dem Gesichtspunkt des Arten- und Naturschutzes. Das trifft vor allem auf die europäischen Länder mit ihrer sehr stark ausgeprägten Landwirtschaft und Landaufgabe zu, in denen der Rückzug 
aus den traditionellen agro-forstlichen Praktiken eine Bedrohung für die Biodiversität darstellt. Wie auch andere Wald-Greifvögel ist der Zwergadler ein geeigneter Bioindikator in den vom Menschen dominierten mediterranen Agroforst-Landschaften, in denen noch immer traditionelle, nicht ganz so intensive Landwirtschaftspraktiken eingesetzt werden. Dank einer Kombination objektiver Technologien wie z.B. GPS-Telemetrie mit einer ausgedehnten (über ganz Spanien) Erfassung markierter Vögel und wesentlich größeren Stichproben als in früheren Untersuchungen können wir mithilfe von GPS-Telemetrie hier erstmals eine quantitative Bewertung der Reviergrößen und der Raumnutzung von Zwergadlern während der Brutzeit vorlegen. Interessanterweise zeigen unsere Ergebnisse eine unterschiedliche Raumnutzung während der Brutzeit und auch, dass die Adler in dieser Zeit für ihre Nahrungsaufnahme sehr weite $(>20 \mathrm{~km})$ Flüge vom Nest aus unternahmen. Daraus ergaben sich deutlich größere Aktionsbereiche als bislang berichtet und überdies in einer extrem exzentrischen Topologie der Territorien. Organisatorische Maßnahmen zum Schutz von Greifvögeln, die Einschränkungen um die Brutgebiete herum vorsehen, sowie Pufferzonen mit willkürlich gesetzten Radien, ergeben für die Zwergadler innerhalb ihrer Aktionsräume große Bereiche, die außerhalb der „eingeschränkten“Gebiete liegen. Deshalb sollten Artenschutz-Maßnahmen den gesamten Bereich der Feld- und Waldhabitate innerhalb der großen Aktionsradien berücksichtigen. Schließlich unterstützen unsere Ergebnisse die Forderung nach einem größer angelegten Management-Ansatz, der über die Einrichtung eines Netzwerks von geschützten Gebieten wie bei Natura 2000 hinausgeht; dies ist für den Arterhalt der mediterranen Greifvögel notwendig.

\section{Introduction}

The study of animals' movement is a subject of major interest in spatial ecology and behavioural ecology (Nathan 2008). Recent advances in tracking technologies have allowed a significant increase in our understanding of the spatial ecology and habitat use of many organisms (Cooke et al. 2004; Rutz and Hays 2009; Bograd et al. 2010; Kays et al. 2015; López-López 2016). This is crucial for conservation planning and to inform management decisions regarding endangered species (Kays et al. 2015). Many raptor species breed in forest environments that are subject to different degrees of human exploitation and where an adequate management of forest resources is of primary importance in order to guarantee long-term preservation of biodiversity. As a matter of fact, forest raptors are generally ecological top predators and have been claimed as adequate surrogates of high biodiversity values, justifying conservation practices based on their role as major ecological indicators (Sergio et al. 2005, 2006).

Forest fragmentation and agricultural intensification have been documented as major causes of biodiversity loss in Europe (Saunders et al. 1991; Donald et al. 2002). In some European countries, agricultural intensification, land abandonment and the withdrawal of traditional management agro-forestry and livestock raising practices have become a threat to biodiversity (Stoate et al. 2001). As a consequence, the European Union has approved a biodiversity strategy to halt the loss of biodiversity and ecosystem services by 2020 (European Resolution of 20 April 2012 of the EU Parliament; http://ec.europa.eu/ environment/nature/biodiversity/comm2006/pdf/EP_resolu tion_april2012.pdf). One of the main goals of this strategy is reaching a more sustainable agriculture and forestry.

Whereas our knowledge of habitat requirements of some endangered raptors has increased in recent years, our knowledge of the spatial ecology and space use of less charismatic but widespread species still remains poorly understood. A good example is the Booted Eagle (Aquila pennata), a fairly abundant raptor species inhabitant of Mediterranean forests for which the study of its spatial ecology and ranging behavior has received little attention in comparison with many other European raptors. Detailed information about movement ecology and ranging behaviour of birds is important not only from the perspective of the basic ecology, but also from the conservation point of view. Fast-moving technological advances, including satellite tracking technologies and other bio-logging innovations, are providing in-depth information on aspects of avian ecology that have thus far been unknown (LópezLópez 2016). Therefore, studies aimed at gaining further insight into issues such as movement behaviour throughout the annual cycle, extension and topology of home range areas, and connection between space use and protected areas, among others, are essential to guarantee an adequate protection of species of conservation interest.

Several studies have focused in basics aspects of the Booted Eagle's ecology; basically, territorial occupancy and breeding behaviour (e.g. Martínez et al. 2006; Pagán et al. 2009; Jiménez-Franco 2014), habitat selection (e.g. Sánchez-Zapata and Calvo 1999; Suárez et al. 2000; Bosch et al. 2005; Barrientos and Arroyo 2014) and diet (e.g. Veiga 1986; Martínez et al. 2004; García-Dios 2006). However, very few studies have focused on movement ecology and space use of this species. Over the last few years, some studies have focused on migratory routes and description of wintering areas (Chevallier et al. 2010; Mellone et al. 2012a, b, 2013, 2015; Vidal-Mateo et al. 2016), taking advantage of satellite tracking technologies. Notwithstanding, space use and ranging behaviour during 
the breeding season still remain poorly understood. To date, very few studies have focused on these topics, and all of them have been conducted using conventional radiotracking technology with limited sample size (Martínez et al. 2007; Díaz-Ruiz and Cebollada-Baratas 2011), which limits spatial accuracy of observations. Hence, this study aims to contribute to filling a substantial gap in our knowledge of the ecology of the species.

Taking advantage of high spatial accuracy of GPS satellite telemetry, the main goals of this study were to: (1) describe and quantify Booted Eagle's home range size and spatial parameters during the breeding season; (2) analyze whether space use varies across the different stages of the breeding season and/or in relation to internal factors such as sex; (3) characterize habitat use in relation to land cover variables; and finally (4) derive management recommendations for the conservation of forest-dwelling raptors in Mediterranean landscapes.

In particular, we tested the following hypotheses: (1) taking into account that the Booted Eagle is a territorial species and thus needs to defend its nest against potential competitors (Martínez et al. 2006; Jiménez-Franco 2014), does home range size and/or territory shape (i.e., topology of the territory) vary across different stages of the breeding season?; (2) considering breeding needs in relation to chick guarding (Newton 1979), is there any difference between sexes in relation to distance to nest site and distance covered within $1 \mathrm{~h}$ over the breeding season? Do females stay closer to the nest during the period in which they are incubating or have nestlings?; (3) considering that most diurnal raptors are central place foragers (Sonerud 1992), do Booted Eagles perform short/far-ranging movements or a combination of both for foraging? Do these foraging patterns vary throughout the time of the day and/or over the breeding season?; and finally, (4) though the Booted Eagle is considered a forest raptor (Cramp and Simmons 1980; Ferguson-Lees and Christie 2001), does habitat use (and particularly forest use) vary over the breeding season? Or, as suggested in previous studies (Martínez et al. 2007), does the probability of forest use decrease with distance from nesting sites?

\section{Materials and methods}

\section{Study species}

The Booted Eagle is a medium-sized, long-lived polymorphic territorial raptor distributed across Europe, northern Africa, the Middle East until Asia and the Indian subcontinent (Cramp and Simmons 1980; Ferguson-Lees and Christie 2001). It is a summer resident in Europe and the majority of individuals overwinter in the Sahel region and tropical Africa after the breeding season (FergusonLees and Christie 2001; Mellone et al. 2013). Interestingly, some individuals do not perform long-distance migrations and winter in the Mediterranean basin (Martínez and Sánchez-Zapata 1999; Baghino et al. 2007), a tendency that has increased in recent years (Morganti 2014; authors unpub. data). The European population has been estimated at 4400-8900 pairs (Burfield 2008) and most of them ( $>60 \%$ of the European population) breed in the Iberian Peninsula (Martí and Del Moral 2003). Due to its extremely large range, the species qualifies as Least Concern worldwide (BirdLife International 2015).

Although traditionally considered a typical forest raptor, the Booted Eagle is a very adaptable species, breeding from small isolated forest patches close to marshes (Suárez et al. 2000), Mediterranean pine forests and woodland areas (Sánchez-Zapata and Calvo 1999) to large continuous forests (Bosch et al. 2005), either deciduous or perennial (i.e., conifers, oaks, corn oaks, etc.). It breeds from sea level up to $2000 \mathrm{~m}$ in southern Europe (Ferguson-Lees and Christie 2001), occupying heterogeneous landscapes characterized by the occurrence of forest areas where nests are placed, interspersed with open areas mainly dominated by scrublands, agricultural areas, crops and pastures (Ferguson-Lees and Christie 2001; García-Dios 2009). Main preys include small to medium-sized birds, reptiles, small mammals, and occasionally insects (Cramp and Simmons 1980; Del Hoyo et al. 1994). Main threats for the species include habitat loss and degradation, electrocution in power lines, direct persecution, occasional forest fires (particularly in Mediterranean pine forests), inadequate forest management (i.e., indiscriminate logging) and disturbance at breeding sites due to construction of roads and forest trails during the breeding season (Ferguson-Lees and Christie 2001; BirdLife International 2015).

\section{Study area and bird tagging}

This study took place in Spain under the framework of the MIGRA project leaded by the Spanish Ornithological Society (SEO/BirdLife). This project is aimed at obtaining a better understanding of the spatial ecology of Iberian migratory birds, with particular focus on their conservation problems either during migration or at their wintering and breeding grounds (for further details, see the project website included in Acknowledgments).

We captured 16 adult breeding Booted Eagles (six males and ten females) in 12 different Spanish provinces (Ávila, Badajoz, Barcelona, Castellón, Ciudad Real, Huelva, Huesca, La Rioja, Lugo, Madrid, Málaga and Murcia) between 2011 and 2014 (five in 2011, three in 2012, three in 2013 and five in 2104). Eagles were captured using a dho-gaza net placed close to active nests with fledglings 
and a live Eagle Owl (Bubo bubo) used as decoy. Ten birds were equipped with $22 \mathrm{~g}$ solar powered GPS-Argos satellite transmitters manufactured by Microwave Telemetry Inc., and six were equipped with 20-23 g GPS-GSM dataloggers from Ecotone (SAKER 4L model). All transmitters were mounted in a backpack configuration and attached using cotton ribbon, designed to ensure that the Teflon harness would fall off at the end of the tag's life. Tags were programmed to collect GPS locations on an hourly basis from 06:00 $\mathrm{h}$ to 22:00 $\mathrm{h}$ (Greenwich Mean Time, GMT) during the breeding season. In all cases, blood samples were collected for sex determination by genetic analysis. All birds bred successfully after marking.

Following similar studies focused on the analysis of spatio-temporal variations in home range behaviour of long-lived territorial raptors (e.g., Campioni et al. 2013; López-López et al. 2014a), we divided each breeding season into three periods: (1) a "pre-laying" period, which spanned from the arrival at breeding areas until egg laying; 2) a "incubation + nestling" period, which comprised an average period of 39 days of incubation (García-Dios 2009) plus the period in which nestlings remained in the nest just before their first flights [52 days on average; García-Dios (2009)]; and finally, a (3) "pre-migration" period, including the dependence period of juveniles once fledged until the onset of autumn migration to their wintering grounds. Besides a detailed inspection of data recorded by satellite telemetry, we conducted field visits each year to each territory to confirm the presence of the individuals in their territories, record breeding behaviour, and eventually, to annotate breeding success. In this manner, we calculated laying date (with an error of \pm 3 days) from the age of the chicks when they were in the nest. Two Booted Eagles tracked in this study failed to breed in two years (one in 2013 and other in 2012 and 2013). In these cases, we only used data for the overall breeding season for analysis, without dividing their recorded data into the three different periods. General information about data used for this study is publicly available in the website of MIGRA project leaded by the Spanish Ornithological Society (http://www.migraciondeaves.org/en/).

\section{Home range size and spatial parameters}

We assessed different levels of space use by means of the $100 \%$ minimum convex polygon (MCP), 95, 75 and $50 \%$ fixed-kernel density estimators. This approach allows comparison with similar studies of other birds in which home range size was calculated and represents a common standard approach in spatial ecology studies (Worton 1989; Cumming and Cornélis 2012). We used the ad-hoc method to calculate the smoothing parameter (Silverman 1986). Following López-López et al. (2014a), we calculated the average spider distance (SD) and the eccentricity (ECC) of home ranges, which both represent a measure of spread of the home range. We calculated the SD as the average distance from the arithmetic centre of all locations to each particular location. SD is useful for developing test of habitat relationships that are not as sensitive to locational error or polygon mismapping as point or polygon methods (Hooge and Eichenlaub 2000). ECC was computed as the distance from the nest used in each particular year to the arithmetic centre of all locations. ECC measures how much the territory deviates from being circular and was used to assess the extent to which the breeding area was centred on the home range (Bosch et al. 2010). We also computed the distance covered in $1 \mathrm{~h}$ (using consecutive locations) and the distance from each location to the nest used the respective year. Finally, we computed the time budget as the frequency of movements throughout the day across the three different periods of the breeding season (LópezLópez et al. 2014b). All estimations of space use were calculated using the "Animal Movement" extension for ArcView 3.2 (Hooge and Eichenlaub 2000) and the Geospatial Modelling Environment software (Beyer 2012).

\section{Habitat use}

To quantify habitat use, we used the land cover layer provided by the European Union CORINE 2006 Land Cover program (http://www.eea.europa.eu/data-and-maps/ data/corine-land-cover-2006-raster-3). We based our habitat use analysis on the comparison between observed values and a set of randomized values generated by Monte Carlo simulations. In doing so, we generated a set of random samples that provided a probability distribution based on real data against which to compare observed values (Gotelli and Ellison 2004). This approach has the advantage over standard statistical methods of not relying on the assumption that data are sampled from a specific theoretical probability distribution (Gotelli and Ellison 2004; Manly 2006). Hence, we firstly sampled the CORINE land cover values of all GPS locations (hereafter called $o b$ served values). Then, we generated 1000 random points within the MCP, which represents the maximum potential area used by each animal (Burt 1943), for each combination of individual and breeding season, and sampled the land use values of these random points (hereafter called expected values). Using these expected values, we generated a probability distribution based on actual data of expected values against which to compare observed values by means of a randomization approach (1000 times) using the "shuffle rows" option in PopTools add-in for Microsoft Excel (Hood 2010). Then, we selected the same number of observed locations for each combination of individual-period-year from this set of expected values and its 1000 
replicates and calculated the summary of land use categories for each replicate. Next, using the Monte Carlo analysis option implemented in PopTools, we selected the real observed values as the dependent range and this set of expected values and its 1000 replicates as test values. In this manner, the program computes how many times the frequency of observed values were equal or lesser (i.e., test criterion) than the expected values in each of the 1000 simulations. Finally, significance probability values, equivalent to traditional $p$ values, were computed by counting the number of randomized cases that resulted in an equal or larger/smaller value than the observed value of land use category, and were then divided by the total number of randomizations (i.e. 1000 in our case). Monte Carlo simulations were run using a two-tailed test with alpha $=0.05$.

In order to facilitate interpretation, we summarized the results of the analysis of habitat use by grouping the original 44 CORINE land cover classes "CLC" (i.e., thirdlevel CORINE codes; full legend available at http://www. eea.europa.eu/data-and-maps/figures/corine-land-cover2006-by-country/legend) into seven main categories: artificial surfaces (CLC codes: 111-142), agricultural areas with arable land (CLC codes: 211-213), agricultural areas with permanent crops and pastures (CLC codes: 221-231), agro-forestry areas (CLC codes: 241-244), forests (CLC codes: 311-313), scrub and/or herbaceous vegetation associations (CLC codes: 321-324), and open spaces, wetlands and water bodies (CLC codes: 331-523). Land cover values were sampled using the Geospatial Modelling Environment software (Beyer 2012).

\section{Statistical analysis}

We used Linear Mixed Models (LMMs) to investigate the effects of the variables of interest (i.e., "period" and "sex") on ranging behaviour. To this end, different measures of home range size and spatial parameters were included as dependent variables in LMMs and each one was tested separately. LMMs are particularly useful for analysing longitudinal data when individuals are measured repeatedly over time (i.e., there is temporal autocorrelation due to repeated measurement of the same individuals; Zuur et al. 2009). Therefore, the variables "period" and "sex" were included as fixed effects in LMMs, whereas "individual" and "year" were included as random factors. Dependent variables were previously log-transformed to meet the assumptions of LMMs (Zuur et al. 2009). All models were validated by checking for homoscedasticity, normality of residuals and by computing relevant model diagnostic graphs (Zuur et al. 2009; results not shown). LMMs were computed using the "nlme" package for R (Pinheiro et al. 2013). Other statistical analyses (i.e., descriptive statistics, Kruskal-Wallis, Mann-Whitney tests and correlations) were computed using STATISTICA version 10.0 (www.statsoft.com). Statistical significance was set at $p<0.05$. Descriptive results are shown as mean \pm standard deviation. Given that measures of home range size do not follow a normal distribution, median and inter-quartile range (IQR) are provided as the best descriptors of central tendency (Gotelli and Ellison 2004).

\section{Results}

According to fieldwork, all birds were territorial breeders. Two individuals were tracked during four consecutive breeding seasons (2011-2014), five individuals were tracked during two consecutive breeding seasons (one during 2011-2012; two during 2012-2013; and two during 2013-2014), and nine individuals were tracked during a single breeding season throughout the study period. In total, we obtained information of 27 different breeding seasons, including 45 complete periods: eight "pre-laying", 17 "incubation + nestling" and 20 "pre-migration" periods, respectively.

Overall, 20,435 GPS fixes were used for the analyses, with an average of $1277 \pm 794$ locations/individual $($ median $=1116, \mathrm{IQR}=724-1819, N=16)$. No differences were found in the number of locations per individual (Mann-Whitney, $H_{15,16}=15.00, \quad p=0.451$ ). Importantly, we first tested the effect of sample size on home-range sizes to assess any possible bias in the estimation of space use due to individual variability. This preliminary analysis showed that there was no significant correlation between the number of recorded locations and home-range size, either using the MCP (Pearson correlation; $\left.r=0.112, r^{2}=0.013, t=0.740, p=0.463\right)$, the $95 \%$ kernel $\left(r=-0.142, \quad r^{2}=0.020, \quad t=-0.939\right.$, $p=0.353)$, the $75 \%$ kernel $\left(r=-0.217, r^{2}=0.047\right.$, $t=-1.456, p=0.153)$ or the $50 \%$ kernel $(r=-0.221$, $r^{2}=0.049, t=-1.488, p=0.144 ; N=45$ in all cases). Similarly, spatial parameters did not correlate with the number of locations per animal (SD: $r=-0.071$, $r^{2}=0.005, \quad t=-0.468, \quad p=0.642, \quad N=45$; $\mathrm{ECC}=r=-0.072, r^{2}=0.005, t=-0.471, p=0.640$, $N=44)$.

\section{Home range size and spatial parameters}

Descriptive values of home range size and spatial parameters are shown in Table 1. Considering the overall breeding period, median size of home range areas were $7.1 \mathrm{~km}^{2}$ (according to kernel $50 \%$ ), $12.5 \mathrm{~km}^{2}$ (kernel $75 \%$ ), $27.8 \mathrm{~km}^{2}$ (kernel $95 \%$ ), and $486.2 \mathrm{~km}^{2}$ (MCP). Univariate comparisons showed no differences in home range size between periods (Kruskal-Wallis, K95\%: 
Table 1 Home range size and spatial parameters of 16 adult Booted Eagles (Aquila pennata) tracked by GPS satellite telemetry in Spain over different periods of the breeding season

\begin{tabular}{lcccc}
\hline & Overall breeding season & Pre-laying & Incubation + nestling & Pre-migration \\
\hline MCP & $486.2(302.0-939.7)$ & $146.1(44.9-389.3)$ & $206.5(91.0-343.1)$ & $437.4(207.5-712.9)$ \\
K95 \% & $27.8(15.3-53.2)$ & $41.0(4.1-89.6)$ & $28.9(6.0-39.3)$ & $44.7(26.8-138.7)$ \\
K75 \% & $12.5(6.5-25.5)$ & $19.1(1.3-49.0)$ & $10.9(2.1-22.4)$ & $20.8(7.2-52.4)$ \\
K50 \% & $7.1(3.5-14.8)$ & $11.0(0.7-28.4)$ & $6.3(1.0-13.0)$ & $8.5(3.9-28.2)$ \\
SD & $5430.4(3233.4-8012.4)$ & $5975.8(1090.7-9263.0)$ & $4188.9(1576.7-5732.0)$ & $5744.5(3426.9-10756.3)$ \\
ECC & $3248.1(1877.9-5116.6)$ & $4119.0(143.8-7415.6)$ & $2840.1(1184.3-3441.9)$ & $4236.3(1781.0-6745.7)$ \\
\hline
\end{tabular}

Results are expressed as median and interquartile range (in parentheses)

$M C P$ minimum convex polygon, $K$ fixed-kernel density, $S D$ spider distance, $E C C$ eccentricity. Surface units (MCP and kernels) and distance units (SD and ECC) are expressed in $\mathrm{km}^{2}$ and $\mathrm{m}$, respectively

$H_{2,45}=3.05, \quad p=0.218 ; \quad \mathrm{K} 75 \%: \quad H_{2,45}=1.39$, $p=0.498 ; \quad \mathrm{K} 50 \%: H_{2,45}=0.87, \quad p=0.647 ; \quad \mathrm{MCP}$ : $\left.H_{2,45}=5.82, p=0.055\right)$. Furthermore, according to the results of LMMs, home range size (according to MCP, $\mathrm{K} 95 \%$, K75 \%, and K50 \%) and spatial parameters (i.e., $\mathrm{SD}$ and ECC) did not show significant differences neither in relation to period nor sex (Table 2).

Interestingly, there were differences in the distance to nest site and distance covered within $1 \mathrm{~h}$ in relation to period (Table 2), with larger values for both variables recorded during the "pre-migration period". Again, according to the results of LMMs, no differences were found in these parameters in relation to sex (Table 2).

Booted Eagles showed different levels of space use during the breeding season. With regards to the distance to the nest, Booted Eagles usually remained close to their breeding sites. However, all individuals consistently performed long-distance movements $(>20 \mathrm{~km})$ from the nest during all stages of the breeding season, resulting in large home range areas, and, more interestingly, in a topology of their territory that is extremely eccentric. For example, considering the whole breeding season, $56.11 \%$ of locations were recorded at a distance $<1 \mathrm{~km}$ from the nest $(72.85 \%$ of locations $<3 \mathrm{~km}$ from it) (Fig. 1). Only $15.55 \%$ of locations were recorded $>10 \mathrm{~km}$ from the nest (only $5.84 \%$ of them at a distance $>20 \mathrm{~km}$ ) (Fig. 1). The frequency of locations recorded $<1 \mathrm{~km}$ from the nest was $79.35 \%$ during the pre-laying period, $68.51 \%$ during the "incubation + nestling" period, and $47.27 \%$ during the pre-migration period (Fig. 1). On the contrary, the frequency of locations recorded $>10 \mathrm{~km}$ from the nest accounted for $10.36,12.65$ and $17.58 \%$ of locations recorded during the "pre-laying", "incubation + nestling" and "pre-migration" periods, respectively (Fig. 1). The maximum distances from the nest recorded in this study
Table 2 Linear mixed models of home range size and spatial parameters as response variables

\begin{tabular}{|c|c|c|c|c|}
\hline Variable & Factor & $d f$ & $F$ value & $p$ value \\
\hline \multirow[t]{3}{*}{$\mathrm{MCP}$} & Intercept & 1,20 & 416.465 & $<0.001$ \\
\hline & Period & 2,20 & 2.953 & 0.075 \\
\hline & Sex & 1,12 & 0.002 & 0.962 \\
\hline \multirow[t]{3}{*}{ K95\% } & Intercept & 1,20 & 1938.510 & $<0.001$ \\
\hline & Period & 2,20 & 1.840 & 0.185 \\
\hline & Sex & 1,12 & 0.016 & 0.900 \\
\hline \multirow[t]{3}{*}{ K75 \% } & Intercept & 1,20 & 1718.115 & $<0.001$ \\
\hline & Period & 2,20 & 1.157 & 0.335 \\
\hline & Sex & 1,12 & 0.112 & 0.744 \\
\hline \multirow[t]{3}{*}{ K50 \% } & Intercept & 1,20 & 1571.856 & $<0.001$ \\
\hline & Period & 2,20 & 0.978 & 0.393 \\
\hline & Sex & 1,12 & 0.099 & 0.758 \\
\hline \multirow[t]{3}{*}{ SD } & Intercept & 1,20 & 1285.600 & $<0.001$ \\
\hline & Period & 2,20 & 1.683 & 0.211 \\
\hline & Sex & 1,12 & 0.136 & 0.719 \\
\hline \multirow[t]{3}{*}{$\mathrm{ECC}$} & Intercept & 1,20 & 789.898 & $<0.001$ \\
\hline & Period & 2,20 & 1.544 & 0.238 \\
\hline & Sex & 1,12 & 0.211 & 0.654 \\
\hline \multirow[t]{3}{*}{ Distance to nest } & Intercept & 11,4148 & 620.103 & $<0.001$ \\
\hline & Period & 21,4148 & 577.622 & $<0.001 *$ \\
\hline & Sex & 1,12 & 0.782 & 0.394 \\
\hline \multirow[t]{3}{*}{ Distance in $1 \mathrm{~h}$} & Intercept & 1,8207 & 726.914 & $<0.001$ \\
\hline & Period & 2,8027 & 150.593 & $<0.001 *$ \\
\hline & Sex & 1,11 & 0.378 & 0.551 \\
\hline
\end{tabular}

The variables "period" and "sex" were included as fixed effects and "individual" and "year" were incorporated as random effects (see details in "Materials and methods")

$d f$ degrees of freedom, $M C P$ minimum convex polygon, $K$ fixedkernel density, $S D$ spider distance, $E C C$ eccentricity

Significant values discussed in the main text are highlighted with an asterisk 


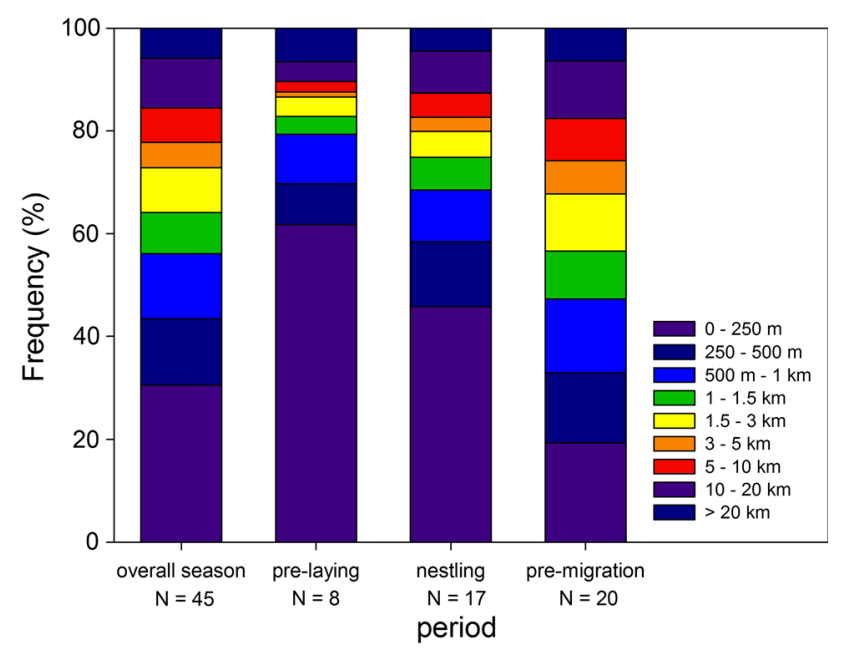

Fig. 1 Frequency of movements in relation to the distance to the nest categorized by distance ranks per periods of the breeding season

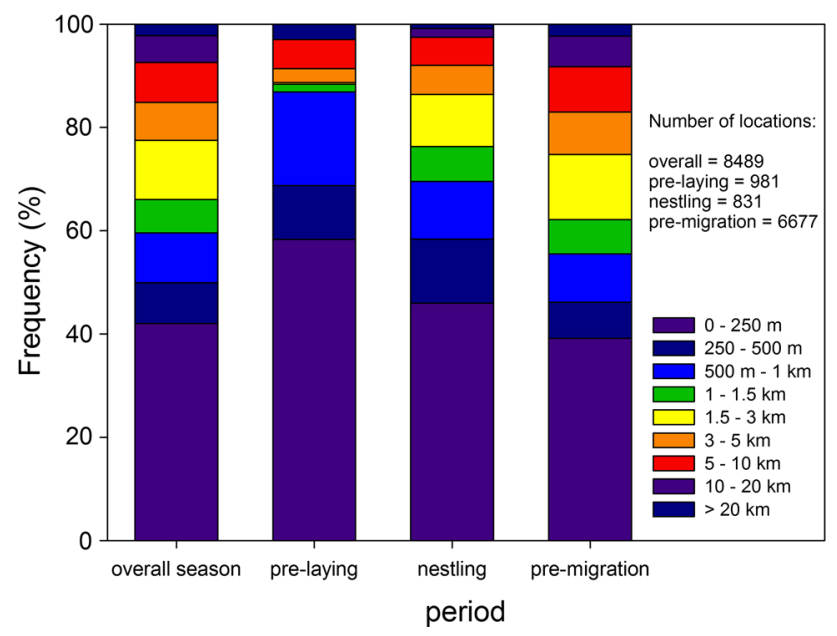

Fig. 2 Frequency of movements recorded at $1 \mathrm{~h}$ intervals categorized by distance ranks per periods of the breeding season

were 62,64 and $95 \mathrm{~km}$, corresponding to locations recorded during the "pre-migration", "incubation + nestling" and "pre-migration" periods, respectively.

With regards to the length of movements recorded at $1 \mathrm{~h}$ intervals, Booted Eagles showed a frequency of short-distance movements ranging from $86.85 \%$ during the "prelaying" period, to $69.55 \%$ during the "incubation + nestling" period, and $55.50 \%$ during the pre-migration period (Fig. 2). In contrast, the frequency of longdistance movements ( $>10 \mathrm{~km}$ in $1 \mathrm{~h})$ was higher in the last stage of the breeding season when eagles were not necessarily so linked to their nest $(8.22 \%$ during the pre-migration period) (Fig. 2).

In relation to the time of day (i.e., time budget), the distribution of the frequency of movements recorded at $1 \mathrm{~h}$ interval varied across the breeding season. Most long-distance movements $(>10 \mathrm{~km})$ took place from $12: 00 \mathrm{~h}$ to
14:00 $\mathrm{h}$ during the "pre-laying" period, from 11:00 $\mathrm{h}$ to 14:00 $\mathrm{h}$ during the "incubation + nestling" period, and spanned notably from 08:00 h to 16:00 h during the "premigration" period (Fig. 3). In contrast, the great majority of short-distance movements $(<1 \mathrm{~km})$ took place after sunset (from 06:00 $\mathrm{h}$ to 08:00 $\mathrm{h}$ ) and in late afternoon until sunrise (from 17:00 h to 22:00 h) (Fig. 3).

\section{Habitat use}

Overall, Booted Eagles mainly used forests (broad-leaved, coniferous and mixed forest depending of the geographic region) and areas dominated by scrublands and/or herbaceous vegetation (mostly sclerophyllous vegetation and transitional zones between woodland-shrub), accounting for $54.43 \%$ of land cover habitat types selected positively during the entire breeding season (Fig. 4). Interestingly, patterns of habitat use changed across the breeding season. Scrublands were mainly used during the "pre-laying" and "incubation + nestling" periods, ranging over forests and agro-forestry areas $(55.56 \%$ of land cover classes positively selected) as the breeding season advanced (Fig. 4). Finally, Booted Eagles made use of forests and scrubland areas in the last stage of the breeding period, making use of artificial areas (i.e., human dominated landscapes) during the "pre-migration" period (Fig. 4). Other habitat types, including non-irrigated arable land, crops, pastures and open areas, were also used, but to a lesser extent.

\section{Discussion}

Obtaining precise estimations of animals' space use is essential to undertake effective management actions, especially in the case of species of conservation concern. In this sense, studies conducted by means of satellite tracking technologies have revolutionized our understanding of behavioural movement patterns; from large-scale continental scale movements such as migration, to short-scale, fine movements during breeding and/or wintering seasons (Kays et al. 2015). Hence, as far as we know, this study provides the first quantitative assessment of the home range size of the Booted Eagle by means of GPS satellite telemetry.

Our results showed greater home range size (i.e., 486.2 and $27.8 \mathrm{~km}^{2}$ according to MCP and $95 \%$ kernel, respectively; detailed results in Table 1) than that reported in previous studies. These works estimated home range size (using MCP) at $28.05 \mathrm{~km}^{2}$ (range $=20.00-36.10 \mathrm{~km}^{2}$ ) for two males, and $73.18 \mathrm{~km}^{2}$ (range $=42.00-105.90 \mathrm{~km}^{2}$ ) for five females radio-tracked in central Spain (Díaz-Ruiz and Cebollada-Baratas 2011). On the other hand, the other available study found in the literature reported an average 

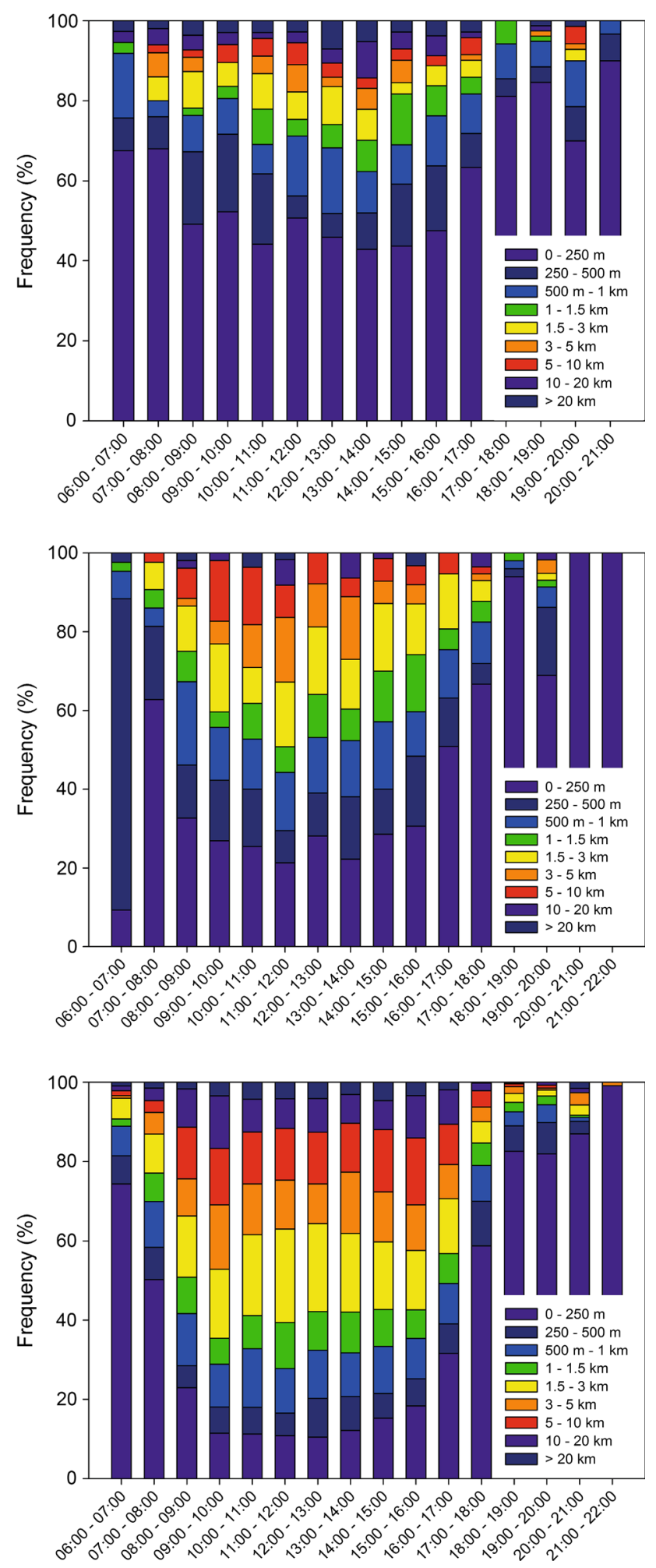

Fig. 3 Time budget showing the frequency of movements throughout the day during the "pre-laying" period (upper panel), "incubation + nestling" period (central panel) and "pre-migration" period (lower panel). Time is expressed as GMT (see "Materials and methods"). Sample size (i.e., number of locations) is the same as in Fig. 2 home range size (according to $95 \%$ fixed kernel density estimator) as $146.0 \mathrm{~km}^{2} \quad$ (range $=88.4-233.3 \mathrm{~km}^{2}$; $N=279$ locations) for two males and four females radiotracked in south-eastern Spain (Martínez et al. 2007). Using the same birds, the latter authors reported home range sizes (according to $\mathrm{MCP}$ ) ranging from $45.42 \mathrm{~km}^{2}$ to $142.66 \mathrm{~km}^{2}\left(51.30-142.66 \mathrm{~km}^{2}\right.$ for males and from 45.42 to $134.84 \mathrm{~km}^{2}$ for females) (Martínez et al. 2011). These differences in home range size can be logically accounted for the different tracking methods, indicating that radiotracking tends to underestimate measures of home range size in comparison with unbiased GPS satellite tracking technologies (Girard et al. 2002; e.g., García-Ripollés et al. 2011; López-López et al. 2014a).

With regards to sex differences in ranging behaviour, previous studies suggested different levels of space use by males and females, with females tending to range across larger areas than males, particularly during the pre-laying and pre-migratory periods (Díaz-Ruiz and Cebollada-Baratas 2011). In contrast, other studies found that these differences were not so evident (Martínez et al. 2007). In our case, no differences in space use were found in relation to sex, suggesting that both males and females are indistinctly able to range extensively. It is likely that sex differences suggested in previous works could be accounted for limited sample size and/or regional particular characteristics. Our design has the advantage that it does not suffer from the biases of previous studies using radio-tracking methods. Regional particular characteristics can also be ruled out since our study also included birds marked in the same study areas (i.e., central and southeastern Spain).

Our study revealed different levels of space use during the breeding season. In general, Booted Eagles concentrated their movements close to the nesting sites during the "pre-laying" period, increasing progressively during the breeding season, with the furthest records from the nest recorded during the "pre-migration" period (Fig. 1). Booted Eagles are long-lived territorial philopatric species that need to establish and defend their territories just after arriving in Europe from spring migration (Jiménez-Franco et al. 2013). Therefore, it is likely that they must restrict their movements in order to defend their territories against intruders, thus avoiding potential intra-specific competition (Martínez et al. 2006).

Interestingly, our results showed that Booted Eagles perform long distance movements (i.e., $>20 \mathrm{~km}$ ) from the nest throughout the breeding season. These movements took eagles as far as $95 \mathrm{~km}$ in linear distance from their nests, returning in successive locations. This pattern was consistently observed in all individuals, especially in six of them breeding in Castellón, Huesca, Madrid (2), Málaga and Murcia provinces (Fig. 5), suggesting that this is a 
Fig. 4 Habitat use of 16 breeding adult Booted Eagles tracked by GPS satellite telemetry in Spain (period 2011-2014). Results were summarized according to the frequency of significant $P$ values obtained from the Monte Carlo simulation analysis recorded for each original 44 CORINE land cover class (at third-level CORINE codes). In order to facilitate interpretation of the results, the most frequently used land cover classes were grouped into seven categories corresponding to structural landscape configuration

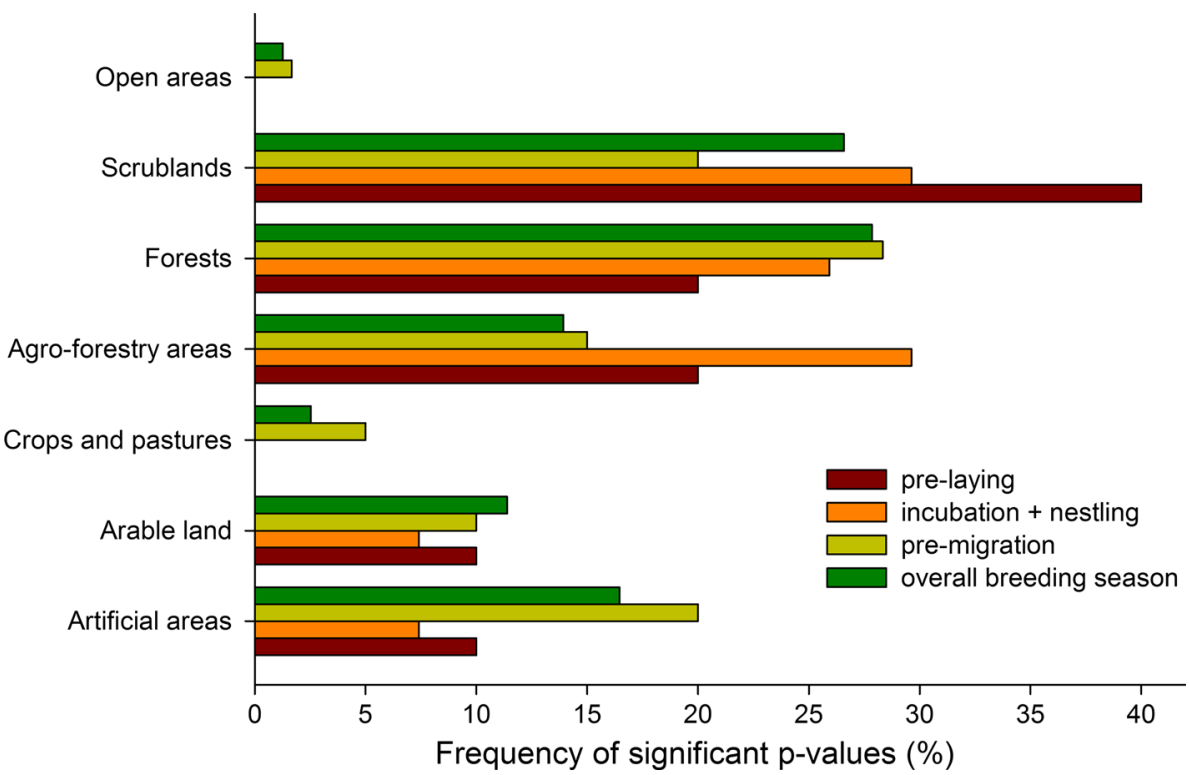

common feature of this species. Taking into account the medium size of this eagle (ca. $1 \mathrm{~kg}$ weight in females and $600 \mathrm{~g}$ in males), this behaviour is particularly demanding in terms of energy expenditure, which accentuates during the period in which birds are incubating or have nestlings. The answer to this question of why eagles travel so far seems to be related to prey availability (Martínez et al. 2007; Díaz-Ruiz and Cebollada-Baratas 2011; authors pers. obs.). However, how Booted Eagles obtain a positive energetic balance of such far-ranging movements seems intriguing, especially taking into account that they are single-prey loaders that capture small and medium size preys (i.e., birds, mammals and reptiles). A possible explanation is that most of these long-distance movements took place in central hours of the day, increasing over the breeding season (Fig. 3). Booted Eagles exhibit a typically diurnal behavioural pattern of a central place forager (Orians and Pearson 1979), using a combination of flapping, soaring and gliding flight modes for displacement. Thereby, eagles take advantage of thermal uplift in central hours of the day to make these long-distance outward movements from breeding sites to foraging areas and the corresponding return trips, resulting in lower energy expenditure and a positive energetic gain (Houston and McNamara 1985). A similar behaviour where birds alternate short and long trips in a dual alternative foraging strategy has also been observed in seabirds tracked by satellite telemetry (Shoji et al. 2015).

Unlike other European forest raptors, such as the Northern goshawk (Accipiter gentilis), the Eurasian sparrowhawk (Accipiter nisus), or the Honey buzzard (Pernis apivorus), to cite a few examples, the Booted Eagle cannot be considered a typical forest raptor (Cramp and Simmons
1980; Ferguson-Lees and Christie 2001). Our results of habitat use confirm this claim, showing that Booted Eagles use forest areas essentially for nesting, and move to areas usually far from their nesting sites for foraging (Fig. 5). In some cases, Booted Eagles build their nests in large trees close to human constructions, roads and trails, reflecting a certain degree of tolerance with human presence (Suárez et al. 2000); which has been associated with a likely increase in the availability of its potential prey within urban areas (Palomino and Carrascal 2007). Our results show that foraging areas are mainly characterized by a mixture of mosaic landscapes dominated by Mediterranean scrublands, agro-forestry areas (fundamentally non-irrigated arable lands), open areas, crops and pastures. This confirm previous works in which the proportion of forest cover was the best predictor of the species occurrence at a small scale and the amount of edge habitat between forest and extensive agriculture was the best predictor at larger scales (Sánchez-Zapata and Calvo 1999). In addition, our results agree with Martínez et al. (2007), who showed that the probability of forest use strongly decreased with distance from nesting sites.

The Booted Eagle could be considered as an adequate bioindicator of human-dominated agro-forestry landscapes in which low-intensity traditional agricultural practices still persist. However, these Mediterranean landscapes are being subject to increasing human alteration, being replaced by intensive agricultural practices where pesticides and other biocides are extensively used, resulting in lower prey availability and consequent biodiversity loss (Saunders et al. 1991; Stoate et al. 2001; Donald et al. 2002). In addition, habitat destruction due to forest fragmentation and disturbance due to uncontrolled logging 
Fig. 5 Example of home range areas of six territorial Booted Eagles tracked by GPS satellite telemetry in Spain. Home range sizes are shown according to minimum convex polygon (solid line) and 95, 75 and $50 \%$ kernel density contours (from lighter to darker shaded grey areas, respectively). Booted Eagles range across extensive foraging areas, most of them outside the European Natura 2000 network of protected areas (dotted areas). The panels show six different eagles tracked in the provinces of Madrid (upper panel), Castellón (centre left), Murcia (centre right), Málaga (lower left) and Huesca (lower right)
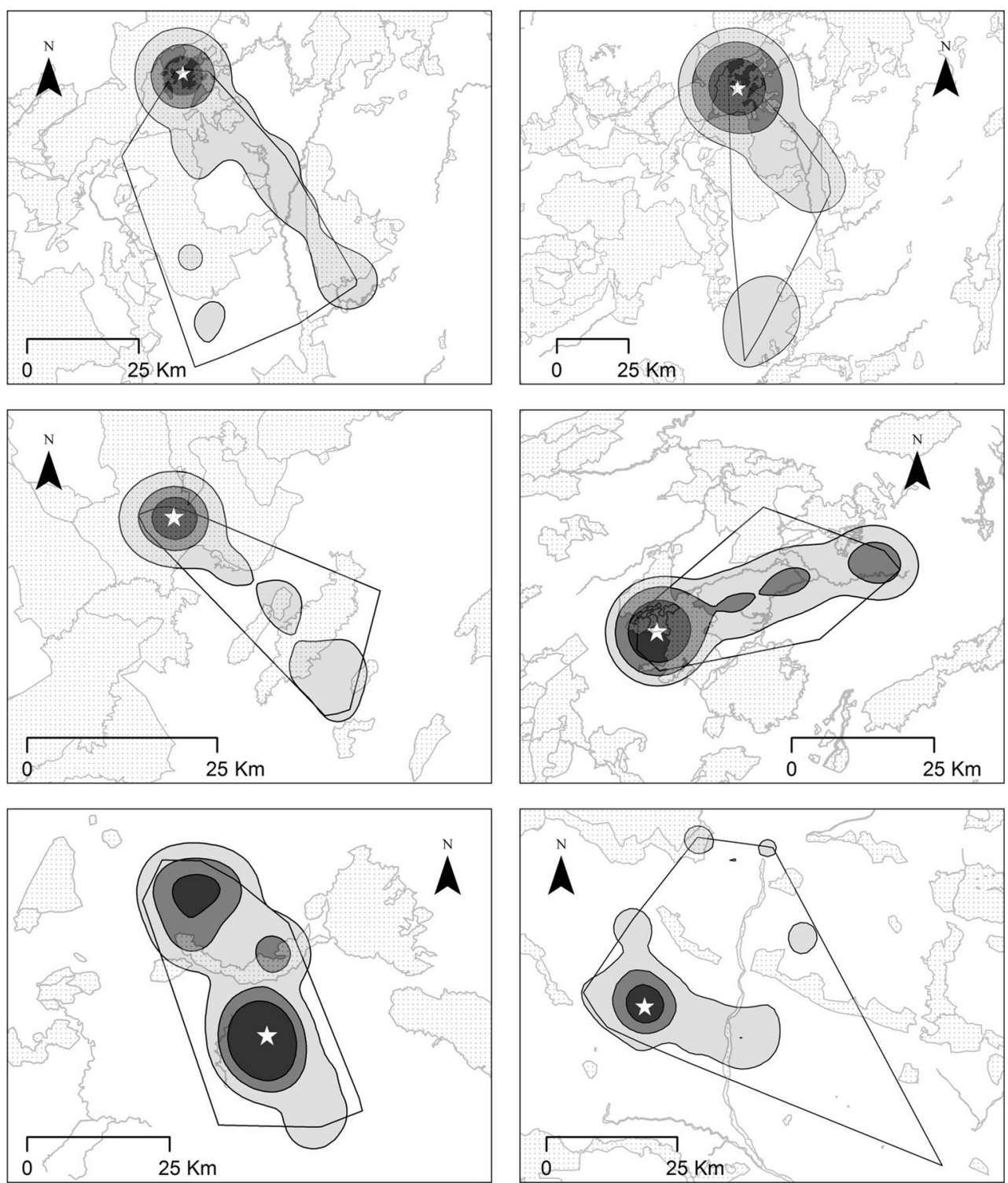

activities during breeding also constitute potential threats for the species (García-Dios 2009).

Overall, one of the most important results of this study is the large size of home range areas and, particularly, the high eccentric topology of the territories. This has important implications from the conservation point of view. Habitually, management measures established by land managers and public administration are based on setting restrictions around nesting sites using buffer areas of arbitrary radii (normally between $500 \mathrm{~m}$ and $1 \mathrm{~km}$ for forest raptors) (Fernández-Juricic et al. 2005). Taking into account that Booted Eagles concentrate almost half of their movements within a $1 \mathrm{~km}$ radius around their nest (i.e., $56.11 \%$ for the overall season; 79.35, 68.51 and $47.27 \%$ for the pre-laying, incubation + nestling, and pre-migration periods, respectively; Fig. 1), this allows encompassing at least core areas, which is important for limiting potential disturbance activities (e.g., forestry works, logging, opening of new paths and tracks, etc.). However, our results also evidence that using these measures as the only "proxy" for conservation of forest raptors clearly results in large areas of their home ranges laying outside the "restriction" areas. Therefore, conservation measures should take into account the full range of agroforestry habitats encompassed within the home range. This also applies to the figures of protection such as Special Protected Areas for Birds and natural parks included in the NATURA 2000 network. Most of these areas were designed taking into account only the most suitable breeding habitats for birds (López-López et al. 2007), excluding the surrounding landscapes where many forest-dwelling species forage (Carrete and Donázar 2005; Martínez et al. 2007). This is a similar conservation problem affecting other 
species inhabiting Mediterranean landscapes, such as the endangered Bonelli's Eagle (Aquila fasciata) or the Eurasian Eagle-Owl (Bubo bubo), which have to move outside protected areas for foraging. As a consequence, it results in an edge effect associated with protected areas, where mortality risks are higher, mainly due to electrocution in power lines (Pérez-García et al. 2011). In conclusion, our results support the claim that a large-scale management approach beyond the establishment of a closed network of protected areas is necessary for the conservation of Mediterranean raptors. This approach should include measures aimed at favouring the maintenance of low-intensity agro-forestry activities in which prey availability, especially rabbits (Oryctolagus cuniculus) is higher (Moreno and Villafuerte 1995). Finally, our study reveals, once again, that animal monitoring by means of satellite telemetry is an essential tool not only for the study of the organisms' basic ecology, but also to determine which areas are of priority concern for an adequate conservation planning.

Acknowledgments All information about tagged eagles has been obtained in the framework of the 'Migra' project (http://www.migra ciondeaves.org/en/) developed by SEO/BirdLife and funded by Iberdrola Foundation Spain. The Extremadura Regional Government provided information on two tagged Booted Eagles (special thanks to Á. Sánchez, D. Rivera and J.M. Abad). Grefa, Comunidad de Madrid and Generalitat Valenciana (Servicio de Vida Silvestre) provided fieldwork material. Different people from La Rioja Government Conservation and Biodiversity from Dirección General de Medio Natural, forest agents from Castellón, Huelva, Málaga and Madrid, SEO-Málaga Ornithological Group, Marismas del Odiel Natural Park, Montes de Málaga Natural Park, Cabañeros National Park, FAB, GIA-León, GOB, Numenius, Research Group in Mediterranean Ecosystems from University of Murcia helped during fieldwork and location of pairs. We would like to thank Á. Gómez-Manzaneque, A. Llopis, A. Leal, A. Planella, B. Fuertes, C. Pino, C. Ponce, C. Rodríguez, D. Miguélez, E. Herrero, E. Miera, E. Navarro, F. Bustamante, F. de la Cruz, F. Ortega, G. Sierra, G. Negrete, H. Astiárraga, I. Castaño, I. Gámez, I. García, J. Bosch, J.A. Cortés, J.E. Martínez, J.F. Calvo, J.F. Pedreño, J.C. del Moral, J. Robres, J.J. Jiménez, J.M. Abad, J.M. Sayago, L.A. Ramos, M. Aguilera, M. Moreno, M.V. Jiménez, N. Rodríguez, Ó. Rivas, P. Díaz, R.A. Haro, R. Ruiz, R. Prades and T. Álvarez. Frédéric Jiguet and an anonymous reviewer made valuable comments on the original manuscript. Pascual López-López is supported by a 'Juan de la Cierva-incorporación'postdoctoral grant of the Spanish Ministry of Economy and Competitiveness (Reference IJCI-201419190). This work complies with the current environmental laws in Spain and all necessary permissions to catch eagles and deploy transmitters were provided by the environmental departments of regional governments (Andalucía, Cataluña, Castilla-La Mancha, Castilla y León, Comunidad Valenciana, Extremadura, Galicia, La Rioja, Madrid and Región de Murcia). The funders had no role in study design, data collection and analysis, decision to publish, or preparation of the manuscript.

\section{References}

Baghino L, Premuda G, Gustin M, Corso A, Mellone U, Cardelli C (2007) Exceptional wintering and spring migration of the booted eagle Hieraaetus pennatus in Italy in 2004 and 2005. Avocetta 31:47-52
Barrientos R, Arroyo B (2014) Nesting habitat selection of Mediterranean raptors in managed pinewoods: searching for common patterns to derive conservation recommendations. Bird Conserv Int 24:138-151

Beyer HL (2012) Geospatial modelling environment (Version 0.7.2.0). (software). http://www.spatialecology.com/gme. Accessed 1 Oct 2015

BirdLife International (2015) Species factsheet: Hieraaetus pennatus. http://www.birdlife.org. Accessed 1 Aug 2015

Bograd SJ, Block BA, Costa DP, Godley BJ (2010) Biologging technologies: new tools for conservation. Introduction. Endanger Species Res 10:1-7

Bosch J, Borrás A, Freixas J (2005) Nesting habitat selection of booted eagle Hieraaetus pennatus in Central Catalonia. Ardeola 52:225-233

Bosch R, Real J, Tintó A, Zozaya EL, Castell C (2010) Home-ranges and patterns of spatial use in territorial Bonelli's Eagles Aquila fasciata. Ibis 152:105-117

Burfield IJ (2008) The conservation status and trends of raptors and owls in Europe. AMBIO 37:401-407

Burt WH (1943) Territoriality and home range concepts as applied to mammals. J Mammal 24:346-352

Campioni L, Delgado MM, Lourenço R, Bastianelli G, Fernández N, Penteriani V (2013) Individual and spatiotemporal variations in the home range behaviour of a longlived, territorial species. Oecologia 172:371-385

Carrete M, Donázar JA (2005) Application of central-place foraging theory shows the importance of Mediterranean dehesas for the conservation of the cinereous vulture, Aegypius monachus. Biol Conserv 126:582-590

Chevallier D, Jiguet F, Nore T, Baillon F, Cavallin P (2010) Satellite tracking of a Booted Eagle Aquila pennata during migration. Ringing Migr 25:62-64

Cooke SJ, Hinch SG, Wikelski M, Andrews RD, Kuchel LJ, Wolcott TG, Butler PJ (2004) Biotelemetry: a mechanistic approach to ecology. Trends Ecol Evol 19:334-343

Cramp S, Simmons KEL (1980) The birds of western palaearctic. Oxford University Press, Oxford

Cumming GS, Cornélis D (2012) Quantitative comparison and selection of home range metrics for telemetry data. Divers Distrib 18:1057-1065

del Hoyo J, Elliott A, Sargatal J (1994) Handbook of the birds of the World, vol. 2: New World Vultures to Guineafowl. Lynx Edicions, Barcelona

Díaz-Ruiz J, Cebollada-Baratas F (2011) Monitoring and conservation of booted eagle (Aquila pennata) in the Sierra de Guadarrama (Central Spain). In: Zuberogoitia I, Martínez JE (eds) Ecology and conservation of European forest-dwelling raptors. Diputación Foral de Bizkaia, Bilbao, pp 93-98

Donald PF, Pisano G, Rayment MD, Pain DJ (2002) The Common Agricultural Policy, EU enlargement and the conservation of Europe's farmland birds. Agric Ecosyst Environ 89:167-182

Ferguson-Lees J, Christie DA (2001) Raptors of the world. Christopher Helm, London

Fernández-Juricic E, Venier MP, Renison D, Blumstein DT (2005) Sensitivity of wildlife to spatial patterns of recreationist behavior: a critical assessment of minimum approaching distances and buffer areas for grassland birds. Biol Conserv 125:225-235

García-Dios IS (2006) Dieta del aguililla calzada Hieraaetus pennatus en el sur de Ávila: importancia de los paseriformes. Ardeola 53:39-54

García-Dios IS (2009) Aguililla calzada-Hieraaetus pennatus. In: Salvador A, Bautista LM (eds) Enciclopedia Virtual de los Vertebrados Españoles. Museo Nacional de Ciencias Naturales, Madrid. http://www.vertebradosibericos.org/. Accessed 1 Oct 2015 
García-Ripollés C, López-López P, Urios V (2011) Ranging behaviour of non-breeding Eurasian Griffon Vultures Gyps fulvus: a GPS-telemetry study. Acta Ornithol 46:127-134

Girard I, Ouellet JP, Courtois R, Dussault C, Breton L (2002) Effects of sampling effort based on GPS telemetry on home-range size estimations. J Wildl Manag 66:1290-1300

Gotelli NJ, Ellison AM (2004) A primer of ecological statistics. Sinauer Associates, Sunderland

Hood GM (2010) PopTools version 3.2.5. http://www.poptools.org

Hooge PN, Eichenlaub B (2000) Animal movement extension to Arcview, ver. 2.0. Alaska Science Center-Biological Science Office. U.S. Geological Survey, Anchorage

Houston AI, McNamara JM (1985) A general theory of central place foraging for single-prey loaders. Theor Popul Biol 28:233-262

Jiménez-Franco MV (2014) Territorial occupancy models in forest raptor populations. Ph.D. Dissertation. University of Murcia, Spain

Jiménez-Franco MV, Martínez JE, Pagán I, Calvo JF (2013) Factors determining territory fidelity in a migratory forest raptor, the Booted Eagle Hieraaetus pennatus. J Ornithol 154:311-318

Kays R, Crofoot MC, Jetz W, Wikelski M (2015) Terrestrial animal tracking as an eye on life and planet. Science 348: aaa2478

López-López P (2016) Individual-based tracking systems in ornithology: welcome to the era of big data. Ardeola 63(1). doi:10. 13157/arla.63.1.2016.rp5

López-López P, García-Ripollés C, Soutullo A, Cadahía L, Urios V (2007) Are important bird areas and special protected areas enough for conservation? The case of Bonelli's eagle in a Mediterranean area. Biodivers Conserv 16:3755-3780

López-López P, García-Ripollés C, Urios V (2014a) Food predictability determines space use of endangered vultures: implications for management of supplementary feeding. Ecol Appl 24:939-949

López-López P, Gil JA, Alcántara M (2014b) Post-fledging dependence period and onset of natal dispersal in Bearded Vultures (Gypaetus barbatus): new insights from GPS satellite telemetry. J Raptor Res 48:173-181

Manly BFJ (2006) Randomization, bootstrap and monte carlo methods in biology. Chapman \& Hall/CRC, London

Martí R, Del Moral JC (eds) (2003) Atlas de las Aves Reproductoras de España. Dirección General de la Conservación de la Naturaleza. Sociedad España de Ornitología, Madrid

Martínez JE, Sánchez-Zapata JA (1999) Invernada de aguililla calzada (Hieraaetus pennatus) y culebrera europea (Circaetus gallicus) en España. Ardeola 46:93-96

Martínez JE, Cremades M, Pagán I, Calvo JF (2004) Diet of booted eagles Hieraaetus pennatus in southeastern Spain. In: Chancellor RD, Meyburg BU (eds) Raptors worldwide: proceedings of the VI World conference on birds of prey and owls, Budapest, Hungary, 18-23 May 2003. World Working Group on Birds of Prey and Owls \& MME/Birdlife Hungary, Berlin \& Budapest, pp 593-599

Martínez JE, Pagán I, Calvo JF (2006) Factors influencing territorial occupancy and reproductive output in the Booted Eagle Hieraaetus pennatus. Ibis 148:807-819

Martínez JE, Pagán I, Palazón JA, Calvo JF (2007) Habitat use of booted eagles (Hieraaetus pennatus) in a special protection area: implications for conservation. Biodivers Conserv 16:3481-3488

Martínez JE, Pagán I, Jiménez-Franco MV, Calvo JF (2011) Ecology of the Booted Eagle in semiarid Mediterranean landscapes. In: Zuberogoitia I, Martínez JE (eds) Ecology and conservation of European forest-dwelling raptors. Diputación Foral de Vizcaya, Bilbao, pp 226-233

Mellone U, Klaassen RHG, García-Ripollés C, Limiñana R, LópezLópez P, Pavón D, Strandberg R, Urios V, Vardakis M, Alerstam $\mathrm{T}$ (2012a) Interspecific comparison of the performance of soaring migrants in relation to morphology, meteorological conditions and migration strategies. PLoS One 7:e39833

Mellone U, López-López P, Limiñana R, Urios V (2012b) Wintering habitats of Eleonora's falcons Falco eleonorae in Madagascar. Bird Study 59:29-36

Mellone U, De La Puente J, López-López P, Limiñana R, Bermejo A, Urios V (2013) Migration routes and wintering areas of Booted Eagles Aquila pennata breeding in Spain. Bird Study 60:409-413

Mellone U, De La Puente J, López-López P, Limiñana R, Bermejo A, Urios V (2015) Seasonal differences in migration patterns of a soaring bird in relation to environmental conditions: a multiscale approach. Behav Ecol Sociobiol 69:75-82

Moreno S, Villafuerte R (1995) Traditional management of scrubland for the conservation of rabbits Oryctolagus cuniculus and their predators in Doñana National Park, Spain. Biol Conserv 73:81-85

Morganti M (2014) The potential of migratory birds to adapt to global change: lessons from European long distance migrants and Iberian Blackcaps. PhD thesis, Universidad Complutense de Madrid, Madrid

Nathan R (2008) An emerging movement ecology paradigm. Proc Natl Acad Sci 105:19050-19051

Newton I (1979) Population ecology of raptors. T \& AD Poyser, Ltd., London

Orians GH, Pearson NE (1979) On the theory of central place foraging. In: Horn DJ, Mitchell RD, Stairs GR (eds) Analysis of ecological systems. The Ohio State University Press, Columbus, pp 154-177

Pagán I, Martínez JE, Calvo JF (2009) Territorial occupancy and breeding performance in a migratory raptor do not follow ideal despotic distribution patterns. J Zool 279:36-43

Palomino D, Carrascal LM (2007) Habitat associations of a raptor community in a mosaic landscape of Central Spain under urban development. Landsc Urban Plan 83:268-274

Pérez-García JM, Botella F, Sánchez-Zapata JA, Moleón M (2011) Conserving outside protected areas: edge effects and avian electrocutions on the periphery of special protection areas. Bird Conserv Int 21:296-302

Pinheiro JD, Bates S, Debroy D, Sarkar, R Development Core Team (2013) "nlme": linear and nonlinear mixed effects models. R package version 3.1-109. http://cran.r-project.org/web/packages/ nlme/. Accessed 1 Oct 2015

Rutz C, Hays GC (2009) New frontiers in biologging science. Biol Lett 5:289-292

Sánchez-Zapata JA, Calvo JF (1999) Raptor distribution in relation to landscape composition in semi-arid Mediterranean habitats. J Appl Ecol 36:254-262

Saunders DA, Hobbs RJ, Margules CR (1991) Biological consequences of ecosystem fragmentation: a review. Conserv Biol 5:18-32

Sergio F, Newton I, Marchesi L (2005) Conservation: top predators and biodiversity. Nature 436:192

Sergio F, Newton I, Marchesi L, Pedrini P (2006) Ecologically justified charisma: preservation of top predators delivers biodiversity conservation. J Appl Ecol 43:1049-1055

Shoji A, Aris-Brosou S, Fayet A, Padget O, Perrins C, Guilford T (2015) Dual foraging and pair-coordination during chick provisioning by Manx shearwaters: empirical evidence supported by a simple model. J Exp Biol 218:2116-2123

Silverman BW (1986) Density estimation for statistics and data analysis. Chapman and Hall, London

Sonerud GA (1992) Functional responses of birds of prey: biases due to the load-size effect in central place foragers. Oikos 63:223-232 
Stoate C, Boatman ND, Borralho RJ, Carvalho CR, De Snoo GR, Eden P (2001) Ecological impacts of arable intensification in Europe. J Environ Manage 63:337-365

Suárez S, Balbontín J, Ferrer M (2000) Nesting habitat selection by booted eagles Hieraaetus pennatus and implications for management. J Appl Ecol 37:215-223

Veiga JP (1986) Food of the booted eagle (Hieraaetus pennatus) in Central Spain. J Raptor Res 20:120-123

Vidal-Mateo J, Mellone U, López-López P, De La Puente J, GarcíaRipollés C, Bermejo A, Urios V (2016) Wind effects on the migration routes of trans-Saharan soaring raptors: geographical, seasonal and interspecific variation. Curr Zool. doi:10.1093/cz/ zow008

Worton BJ (1989) Kernel methods for estimating the utilization distribution in home range studies. Ecology 70:164-168

Zuur A, Ieno EN, Walker N, Saveliev AA, Smith GM (2009) Mixed effects models and extensions in ecology with R. Springer, New York 